\title{
Medansvar og fagligt engagement gennem digitale skriveøvelser
}

Henriette Roued-Cunliffe, adjunkt, Det Informationsvidenskabelige Akademi, Københavns Universitet.

Volkmar Engerer, lektor, Det Informationsvidenskabelige Akademi, Københavns Universitet.

\section{Faglig artikel (bedømt af redaktionen)}

Vi rapporterer om vores forsøg på at promovere medansvar og fagligt engagement blandt vores studerende gennem digitale skriveøvelser. Disse kombinerer skriftlighed i loering (som en refleksionsfremmende og forpligtende øvelse) med de kollaborative muligheder, der ligger $i$ at benytte digitale platforme. Dybde i loering og reflekteret/reflekterende feedback er aspekter, som bliver centrale, når fagligt indhold på skrift indlejres $i$ en digital loeringskontekst. I artiklen tages udgangspunkt i TEACHs universitetspoedagogiske initiativer inden for skriftlig loering og erfaringerne fra universitetspaedagogikum. Forfatterne afprøvede nogle af disse idéer i form af kollaborative skriveøvelser på et bachelorkursus på Det Informationsvidenskabelige Akademi (Københavns Universitet). Forfatternes praktiske fremgangsmåde dokumenteres, og der gøres rede for de erfaringer, de har gjort sig. I den forbindelse diskuteres aspekter som tekstnoere vs. åbne spørgsmål, de studerendes motivation for skrivning, deres vurdering af egen arbejdsindsats, en vurdering af de studerendes tidsforbrug og de studerendes holdning over for den foretrukne feedback - underviserens eller peer-topeer. Der afsluttes med anbefalinger, som baserer sig på dette forsøg. ${ }^{1}$

\section{Introduktion}

Denne artikel handler om, hvordan vi gennem digitale skriveøvelser har forsøgt at øge de studerendes medansvar og faglige engagement i og uden for undervisningen. I forbindelse med et fælles kursus i Digitale Videnssystemer på 3. semester af bacheloruddannelsen i informationsvidenskab og kulturformidling har vi arbejdet med forskellige typer af skriveøvelser, hvor målet var at gøre de studerende bevidste om sammenhængen mellem læste tekster fra litteraturlisten, fagets pointer og deres egen viden. I forløbet har vi kombineret den ene forfatters undervisningserfaring med den anden forfatters nye viden fra kurset Universitetspædagogik på Humaniora (2014/2015).

\footnotetext{
${ }^{1}$ Vi siger i øvrigt tak til Diana Wolff Bie og Lone Kannegaard Johannessen for hjælp med korrekturlæsning af udkastet til manuskriptet, samt tak til redaktørerne af DUT for konstruktiv feedback.
} 
Skriftlighed i læring og undervisning er blevet et vigtigt aspekt af en universitetsuddannelse, som et blik på TEACH, det universitetspædagogiske center ved Københavns Universitet, bekræfter. Både udvikling af de studerendes skriftlige færdigheder og inddragelse af skriftlighed i undervisning og læring er centrale strategiske mål i centerets undervisningsudbud og projekter (Bødtcher-Hansen, 2015). Overordnet set er TEACH's fokus på inddragelse af skriftlighed sigtet på især de tidlige semestre på bacheloruddannelserne. Her tages udgangspunkt i spørgsmålet, “[h]vorfor [...] de nye studerende [er] bedre mundtligt end skriftligt, og hvorfor [de] har svært ved at læse akademiske tekster" (Ledelse og kommunikation, 2013). Problemet ligger, ifølge $\mathrm{TEACH}$, i overgangen fra gymnasieverdenen til universitetet, hvor undervisere skal støtte de studerendes akademiske udvikling i de første semestre.

I forlængelse af denne beskrivelse nævnes to pædagogiske emner, hvor skrivning indgår som kritisk akademisk færdighed (Ledelse og kommunikation, 2013): For det første er skriftlighed et redskab til læring og støtter "den dybe faglighed" og de studerendes evne til akademisk skrivning generelt. For det andet fremhæves skrivegrupper, hvor de studerende "[...] giver respons på hinandens ideer og tekstudkast undervejs i skriveprocessen [... og] styrker deres skriveproces og skriftlige produkt." Som vi læser TEACH's to udspil ift. skriftlighedens rolle i universitetsuddannelser, retter det ene, punkt 1, sig imod en kvalitet i læring, der opstår, når de studerende reflekterer kognitivt over stoffet, hvorimod det andet, punkt 2, fremhæver den faglige samtale med andre eller med underviseren om det endelige skriftlige produkt, de studerende skal skabe. Vi mener, at begge aspekter, det kognitive og det diskursive, dækker over relevante dimensioner af skriftlig læring, og at begge, selvom de for de studerende typisk flyder sammen i én aktivitet, skal indgå i praktiske skriveøvelser. Ifm. punkt 1 havde vi i dette pilotprojekt, som beskrives nærmere senere, ikke de metodiske håndtag til at afdække og dokumentere en udvikling af de studerendes faglighed i skriveprocessen (men vi har samlet nogle udsagn relateret til det, som præsenteres længere nede). Hvad punkt 2 angår, skabte vi et læringsmiljø, som støttede respons og dialog i skrivegrupperne mht. forbedring af det skriftlige produkt, både i og uden for undervisningen.

\section{Skriftlighed, feedback og det digitale}

Hvad gør "viden på skrift" så egnet til læring, som TEACH's fokuspunkter ovenfor antyder? Skriftligt fikseret viden er ikke flygtig, som den er ifm. tale. Den står til rådighed i alle læringsfaser, den studerende gennemgår. De studerende kan løbende analysere og modificere deres tekster i en dynamisk skriveproces; samtidigt fremstår teksterne som produkter, der udfordrer den studerende og inviterer til refleksion. Feedback og respons i forhold til skrivning af et fælles produkt lægger op til en "metadiskurs", hvor de studerende holdes fast i fagligheden; det gælder især, hvis feedback også foreligger skriftligt og er permanent. Feedback kan reflekteres over og opsøges, når den studerende har brug for det. I vores egne skriveøvelser opfordrer 
vi de studerende til at give hinanden skriftlig feedback (især vha. Google Docs kommentarfunktion) uden for undervisningen. Vores materiale viser, at nogle gjorde brug af denne mulighed, og senere beskriver vi nogle af de kommentarer, som de studerende gav deres medstuderende med på vejen.

I dette skriveprojekt tænkte vi mulighederne af de digitale medier ind: På hvilken måde kan det digitale støtte skriftlighedens styrker? Ny teknologi gør det muligt, at to eller flere studerende arbejder sammen omkring ét delt dokument (her Google Docs), enten fra hans/hendes egen computer eller som gruppe, der diskuterer teksten mundtligt og skriver refleksionerne ind i det fælles dokument. Den sidstnævnte setting praktiserede vi i vores undervisning, men opfordrede samtidigt de studerende til at arbejde videre med dokumentet, fx hjemmefra. Det forlænger læringsoplevelsen. Hvorvidt de studerende brugte tid til at arbejde videre med besvarelserne uden for klasselokalet, kan ikke siges med sikkerhed, men ved hjælp af Google Docs' history-funktion kan vi se, hvornår de studerende foretog ændringer - og hvilke. Som eksempel kan vi se, at der i undervisningen den 15.9.2015 skrives en del i dokumentet, og senere samme dag blev der foretaget en kort redigering (kl. 12.17-12.18) og en længere (kl. 21.18-22.06). Denne redigeringsaktivitet fortsatte den følgende dag (16.9.) og intensiveres igen de to dage inden den næste undervisningsgang (20.9. og 21.9.). De andre øvelser peger også på, at læringsaktiviteterne strakte sig langt ud over den normerede undervisningstid.

Feedback i digitale miljøer kan ske hurtigt på online-platforme (Pachler \& Daly, 2011, s. 16) og er ofte med til at motivere læring (Webb \& Powis, 2004, s. 21). ÆEndringsforslag og kommentarer fra gruppemedlemmerne placeres direkte i forbindelse med den tekst, som kommenteres. Samtidig skal feedback på skrift, især kritisk, gennemses af producenten, og der skal overvejes ordvalg og de konsekvenser, en kritik måtte have på tekstforfatteren. Dette kommunikative træk ved den skriftlige kanal kaldes i computermedieret kommunikation for "revisability" (Clark \& Brennan, 1993), hvor en person bevidst reviderer sit budskab inden afsendelse (og forventes at gøre således af modtageren), og hvor "self-repairs" ikke behøver at blive foretaget offentligt i en længere diskurs med tekstforfatteren. Revisability har den læringsmæssige effekt, at en kritisk kommentar får et forpligtende anstrøg, og at den derfor, eksplicit og præcist, skal knyttes til det kommenterede indhold. Det forudsætter kommentatorens intense beskæftigelse med passagens indhold og en formulering af konkrete indholdsmæssige alternativer på skrift. Det fremmer læring. I vores studenterreaktioner, beskrevet nærmere nedenfor, viste det sig, at denne forpligtelse netop blev opfattet af de studerende som "pres" til en meget dybere tilegnelse og forståelse af litteraturen (som vores spørgsmål baserede sig på), grundig analyse af eksisterende besvarelser af gruppen og evnen til at formulere sig eksplicit, konstruktivt og fagligt i den studerendes egne kommentarer. 


\section{Baggrund for skriveøvelserne}

Vi rapporterer i det følgende et forsøg, som vi har udviklet til kurset Digitale Videnssystemer, som er et obligatorisk fag for 3. semester på BA-uddannelsen i Informationsvidenskab og kulturformidling (2012-studieordning). I kurset, som er på 10 ECTSpoint, skulle de studerende skrive en fri skriftlig opgave på 11 sider. Opgaven blev bedømt på opfyldelse af kursets faglige mål (fig. 1).

\begin{tabular}{|l|l|}
\hline Faglige mål & $\begin{array}{l}\text { Eksaminanden kan } \\
\text { - Redegøre for de grundlæggende begreber, teorier og metoder indenfor } \\
\text { emnerne vidensorganisation, informationssøgning og bibliometri. } \\
\text { - Forstå og reflektere over, hvordan grundlæggende teorier og metoder } \\
\text { traditionelt har været anvendt til løsning af problemstillinger inden for in- } \\
\text { formationsvidenskab og kulturformidling. }\end{array}$ \\
- Anvende centrale metoder indenfor vidensorganisation, informationssøg- \\
ning og bibliometri i analyser af problemstillinger inden for informationsvi- \\
denskab og kulturformidling. \\
- Analysere teoretiske og praktiske problemstillinger indenfor biblioteks- og \\
informationsvidenskab samt begrunde og vælge relevante løsningsmodeller. \\
- Identificere problemstillinger inden for informationsvidenskab og kultur- \\
formidling, der kan undersøges af de på modulet introducerede teorier og \\
metoder. \\
- Selvstændigt kunne tage ansvar for egen faglig udvikling og specialisering \\
i forhold til analyser og udvikling af digitale videnssystemer.
\end{tabular}

Fig. 1: Faglige mål for kurset Digitale Videnssystemer.

Nogle af ovenstående formuleringer korresponderer direkte med fagligt engagement, idet akademiske aktiviteter som at 'redegøre', 'forstå' og 'reflektere' udvikles og kommer til udtryk i de skriftlige produkter, både i undervisningen og til eksamen. Derfor har vi lagt vægt på, at de studerende skal klædes på til at forstå og reflektere over kursets teorier og metoder samt blive i stand til at analysere de teoretiske og praktiske problemstillinger, der er inden for faget. Det er disse punkter fra de faglige mål samt den skriftlige opgave, de studerende skulle aflevere til eksamen, som vi forsøgte at aligne undervisningen med gennem digitale skriveøvelser.

Rent praktisk foregik skriveøvelserne ved, at vi i undervisningen tog en pause fra undervisers oplæg, delte de studerende op i grupper og fordelte nogle øvelser således, at hver gruppe på 3-4 studerende skulle besvare et spørgsmål. De studerende blev opfordret til at diskutere spørgsmålet indbyrdes i grupperne og sørge for at skrive deres besvarelse ind i et fælles Google-dokument.

Det har været en vigtig del af disse skriveøvelser, at de er foregået digitalt, idet det har virket mere forpligtende, at både underviser og medstuderende har kunnet følge med i, hvad man skrev, mens man skrev det, og at de studerende arbejdede med ét dokument, hvor de i en dialogisk læringsproces skulle forhandle sig frem til "deres" besvarelse. Tidligere forsøg på at udvikle skriveøvelser i undervisningen har gjort brug af værktøjer som diskussionsfora i Absalon, Wikispaces.com, og Socrative.com uden større held. Til dette formål har det været nødvendigt i stedet at finde 
en platform, hvor flere kunne skrive på samme tid, og hvor det, der blev skrevet, var samlet på samme side. Derfor forsøgte vi i denne forbindelse at gøre brug af Google Docs, som er en del af Google Drev. ${ }^{2}$ Dette har været en stor succes på mange måder. Først og fremmest minder platformen om MS Word og er dermed bekendt for de fleste studerende. Derudover kræver det ikke et login, idet vi delte et link til det pågældende dokument, som alle med linket kan redigere i de fleste browsere. Vi har brugt platformen med op til 20 studerende, der arbejdede i det samme dokument på en gang, uden problemer.

Spørgsmålenes udformning var af forskellig karakter. Vi varierede bevidst mellem mere snævre, tekstnære spørgsmål (se spørgsmål 1 og 4) og opgaver, der kunne løses og besvares på forskellige måder og på grundlag af forskellige informationskilder (se spørgsmål 2 og 3). I vores afsluttende Socrative-session, som vi kommer ind på nærmere nedenfor, er der blevet spurgt til de studerendes holdninger til de to typer spørgsmål.

Eksempler på spørgsmål:

1. Skal information altid være sand? Skal information altid være ny? Forklar I jeres egne ord hvordan talemåden "Viden er magt" indeholder en informationsvidenskabeligt sand kerne.

2. Kom med 3 eksempler på tegnsætnings-markup.

3. Søg i Worldcat.org og find 3 eksempler på metadata fra forskellige bøger for de Dublin core-elementer I har fået tildelt (fx Creator og Coverage).

Hvad har brugere bidraget med gennem kommentar i National Archive i Holland's billedarkiv?

Som afslutning på faget brugte vi online-værktøjet Socrative ${ }^{3}$ til at stille de studerende fire spørgsmål ud over den obligatoriske slutevaluering for at få deres reaktioner på de skriveøvelser, vi havde afprøvet på faget. Det foregik således, at spørgsmålet blev stillet i Socrative som et åbent spørgsmål, hvor de studerende fra deres egne enheder kunne besvare det på skrift og samtidig følge med i, hvad de andre havde svaret.

\footnotetext{
${ }^{2}$ https://drive.google.com

${ }^{3}$ http://www.socrative.com/
} 
De fire spørgsmål lød:

1. Hvor vigtig synes du at skriftlighed er for din uddannelse? Synes du, at kurset Digitale Videnssystemer har udviklet din evne til at skrive faglige tekster?

2. Nogle spørgsmål var tekstnære, mens andre var mere åbne problemstillinger, som tillod forskellige svar og evt. eksempler. Hvordan oplevede du denne forskel og virkede nogle spørgsmål bedre end andre?

3. Hvad var generelt godt ved kursets skriveøvelser?

4. Hvad var ikke optimalt ved vores skriveøvelser - og hvad kunne vi gøre bedre?

I det følgende gennemgår vi nogle af de aspekter af skriveøvelserne, som vi synes fremgår af de studerendes svar.

\section{Tekstnære vs. problematiserende spørgsmål}

I dette skriveprojekt spurgte vi ind til den måde, vi stillede enten tekstnære eller åbne og problematiserende spørgsmål i skriveøvelserne på, og hvordan de studerende har opfattet de forskellige typer spørgsmål samt kombinationen af begge. Der var en større gruppe af studerende, der var glade for variationen mellem de forskellige spørgsmål, men også en del, som syntes, at den ene eller den anden type spørgsmål fungerede bedre. Især var der mange, der forholdt sig til, om spørgsmålene var nemme at forberede sig til, og hvor meget forberedelse de forskellige typer spørgsmål krævede (Udsagn 1).

Udsagn 1:

- "De åbne spørgsmål har vaeret gode når man har forberedt sig. Hvorimod [lukkede spørgsmål er] godt når man ikke har forberedt sig."

- "Nogle spørgsmål tog loengere tid end andre og ganske vist skulle man vore forberedt på forhånd, men der var ingen garanti for at alle i gruppen var forberedt."

- "[...] jeg [var] personligt overhovedet ikke forberedt og derfor var de tekstnoere spørgsmål udfordrende. De åbne spørgsmål kunne man bedre tale sig ind på."

Der forekom forskellige vinkler på dette. Blandt andet blev de åbne spørgsmål af nogle set som svære, fordi man skulle være forberedt med noget viden om emnet for at kunne deltage i diskussionen. Af andre blev de åbne spørgsmål derimod anset for at være lettere at sætte sig ind i uden af have læst. Denne dobbelthed ser vi også i de mere tekstnære spørgsmål, hvor nogle giver udtryk for, at de uden af have forberedt sig kunne slå et svar op i teksten, mens andre måtte indrømme, at de havde svært ved at deltage i de tekstnære spørgsmål, når de ikke havde læst den pågældende tekst. Alt i alt kan man se, at det med at forberede sig og læse til undervisnin- 
gen har været en stor udfordring for de studerende og noget, der blev meget synligt på grund af disse skriveøvelser. Skriftlighed er generelt knyttet til en forpligtigelse over for ens eget produkt - hvorimod det mundtlige medium tillader at gøre nogle forsøg på, i løbet af samtalen, at ramme et relevant svar ved at "tale sig ind på det", som en af de studerende udtrykte det.

De studerende gav også udtryk for nogle mere læringsorienterede holdninger til tekstnære vs. mere åbne spørgsmål (Udsagn 2).

\section{Udsagn 2:}

- "Jeg synes, man loerer mest af at besvare de åbne spørgsmål - krœver mere overblik og at man toenker selv."

- "Spørgsmål med åbne problemstillinger var efter min mening de mest interessante da de lagde op til debat i grupperne."

- "Den ene slags spørgsmål var nok mere en øvelse i klart at kunne gengive/referere nogle pointer fra en tekst. Den anden slags spørgsmål lagde mere op til diskussion og de skulle arbejdes mere med."

De studerende, som tematiserede de læringsmæssige effekter af spørgsmålene fremfor forberedelsesaspektet, anså de åbne spørgsmål som mere effektive i forhold til læring og refleksion. Der var studerende, der mente, at de åbne spørgsmål fungerede aktiverende $\mathrm{i}$ forhold til den enkelte studerende og gruppen. Mht. den mundtlige diskussion i gruppen, der gik forud for det skriftlige produkt i gruppen, var åbne spørgsmål at foretrække, da de åbner op for, at der kan komme divergerende, supplerende eller præciserende bidrag. Også den diskursive beslutningsproces om, hvad der endegyldigt indgår i den skriftlige besvarelse, bliver åbenbart opfattet af de studerende som berigende læringsoplevelse. Tekstnære spørgsmål foretrækkes derimod, når den studerende sidder alene og fordyber sig både i sin egen refleksion og $\mathrm{i}$ det skriftlige produkt. På baggrund af denne viden vil vi næste gang helt klart stille diskussionsspørgsmålene så åbne som muligt for at fremme gruppedialogen i undervisningen. Denne type øvelse kan så suppleres med mere snævre “hjemmeopgaver", som den studerende besvarer alene - og eventuelt efterfølgende, i undervisningen, sammenligner med medstuderendes besvarelser.

\section{Motivation}

Det første spørgsmål vi stillede i spørgeskemaet var, hvor vigtigt de studerende syntes, skriftlighed var for deres uddannelse. Her svarede alle, at det generelt var vigtigt. Der var mange, der udtrykte, at det endda var 'meget' eller 'utroligt vigtigt'. De studerende gav forskellige begrundelser for, hvorfor skriftlighed var så vigtig for deres uddannelse (Udsagn 3). 
Udsagn 3:

- "[...] man skal voere i stand til faglig skriftlig formidling i fag der ikke tillader verbal formidling."

- "[...] da det er den måde hvorpå vi kan udtrykke os i opgaver."

- "[...] da skriftlighed er vores mulighed for at udtrykke os fagligt i "halvdelen" af vores eksamener."

Som man kan se, er de begrundelser, der fremkom om, hvorfor skriftlighed er vigtig i deres uddannelse, meget alignet med den eksamensform, de er udsat for. Med andre ord, skriftlighed er hos mange studerende instrumentelt motiveret, hvilket kan tyde på et øget behov for at bevidstgøre de læringsmæssige fordele af skriftlighed i alle akademiske kontekster for de studerende. En bevidstgørelse af skriftlighedens værdi for dybdelæring og generelle refleksionsevner ville måske kunne sætte et skift fra ekstrinsisk motivation (at skulle lære) til intrinsisk motivation (at ville lære) i gang (Webb \& Powis, 2004, s. 21). Men det er i lyset af disse resultater heller ikke klart, om de studerende rent faktisk er optaget af dybdelæring, som en reviewer bemærkede, eller om de er mere optaget af at bestå eksamen. Disse to ting, eksamen og dybdelæring, virker ikke altid som om, de har sammenhæng med hinanden. Dette dilemma ligger nok bag mange af de studerendes svar. Men vi kan ikke tilbyde en anden tilgang end at bevidstgøre og være i dialog med de studerende omkring deres læring og de læringsmål, de er udsat for i en højere uddannelse, inden for rammerne af vores lille forsøg.

\section{Skriftligt gruppearbejde og arbejdsindsats}

Vi valgte, at der i hver gruppe på skift blev udpeget en person, der skulle være referent og stå for, at der blev skrevet noget ind i et fælles Google-dokument. Samtidigt blev der udpeget en ordstyrer, som havde ansvaret for, at der var noget at skrive ind i dokumentet. Dette gjorde, at der i hver gruppe var to studerende, der blev pålagt et særligt ansvar for, at gruppen fik produceret et svar, og at svaret blev nedskrevet. Denne fremgangsmåde blev udviklet gennem undervisernes afprøvning af forskellige platforme (blandt andet diskussionsfora i Absalon og Wikispaces.com) i forbindelse med universitetspædagogikum.

\section{Udsagn 4:}

- "Folks egen indsats, da der sjoeldent var mere en 1/3 der havde loest."

- "Nogle af spørgsmålene var meget svore. Det var ikke altid at alle havde loest og derfor var det ikke alle, som bidrog til gruppearbejdet."

- "Basalt set er der intet sentiment for at klare skriveøvelserne og gruppeopgaverne. Derfor faldt mange opgaver igennem fordi vi ikke tog ansvar for dem." 
En af de problematikker, de studerende gjorde opmærksom på, var især deres egen og andre studerendes indsats i forhold til undervisningen generelt og skriveøvelserne i særdeleshed (Udsagn 4). En af de studerende vurderede, at der sjældent var mere end en tredjedel af de studerende, der havde læst til timerne. Især var problemet, at de, der ikke havde læst, havde svært ved at bidrage til gruppearbejdet. En anden studerende foreslog dog, at problemet lå i, at der ikke var nogen motivation for de studerendes deltagelse i skriveøvelserne, og derfor tog de studerende simpelthen ikke ansvar for arbejdet. Det har dog været vores oplevelse som undervisere, at mere end en tredjedel havde læst, om end ikke det hele, så noget af materialet til timerne, og at skriveøvelserne i sig selv fungerede som motivation for at gøre dette.

I forbindelse med manglende forberedelse var der også kommentarer i vores slutevaluering af kurset, som gav det indtryk, at de studerende på dette semester følte, at de havde en usædvanlig stor læsebyrde. Dette, kombineret med behovet for at læse for at kunne deltage i skriveøvelserne, gjorde, at nogle studerende følte sig overbebyrdede (Udsagn 5).

Udsagn 5:

- "Det var svoert at finde ud af, hvor meget man skulle forberede sig til lektionerne, for at man kunne få noget ud af gruppearbejdet i lektionen."

- "Teksterne var lange, og det var derfor svort at forbedre sig hjemmefra. Der skulle nok voere foerre spørgsmål, eller mindre tekster."

- "Nogle gange var det svoert at voere i gruppearbejde, når der var skriveøvelser, da der tit var mange, som havde haft svaert ved at forstå teksterne og dermed ville en tavlegennemgang muligvis have hjulpet mere end, at der ikke var nogen som kunne svare på spørgsmålene."

Skriveøvelserne nødvendiggjorde, at de studerende deltog aktivt i undervisningen og dermed var det ikke nemt at komme til at "gemme sig" i mængden på samme måde, som når underviser holder forelæsninger. Dette var en styrke for flere, mens det for andre blev opfattet som meget belastende. Især syntes de studerende, at det var svært at finde ud af, hvordan og hvor meget man skulle forberede sig hjemmefra for at kunne deltage i øvelserne. Dette kunne måske løses i højere grad ved hjælp at en læse-og litteraturvejledning. Derudover syntes mange deltagere, at teksterne var for lange og for svære, og der var også enkelte studerende, der ville have foretrukket, at undervisningen i stedet udelukkende havde været baseret på forelæsninger. 
Udsagn 6:

- "Når man er i gruppe sammen, og halvdelen af gruppen ikke er forberedt. Det kom også som en stor overraskelse med alt dette gruppearbejde, som vi normalt ikke gør."

- "At I tvinger de studerende til at arbejde sammen. På den måde har det varet godt på det sociale aspekt."

- "Det styrkede vores gruppearbejde, og man fik bedre overblik over teksterne - og genopfriskede dem igen."

Der var en dobbelthed omkring gruppearbejde, som gik på, at det styrker de studerendes kompetencer generelt, men samtidig er det svært at komme overens med, at andre studerende ikke er velforberedte og derfor ikke bidrager til gruppen (Udsagn 6). At skrive sammen - og ikke kun at tale sammen - er åbenbart i særlig høj grad en katalysator for kollaborativt arbejde og det at føle sig som del af et team, som vi fortolke det at være "godt på det sociale aspekt" og "styrket gruppearbejde" i ovenstående udsagn.

\section{Tid til fordybelse}

Udsagn 7:

- "[...] og vi fik ikke tid til at gå ordentlig i dybden med dem [...]."

- "I...] men meget tidskraevende og kunne sjoeldent - hvis aldrig - nås inden for undervisningstiden."

- "Vi fik ikke nok tid nogen gange. 10-15 minutter til dybdegående spørgsmål er ikke nok."

En af de helt store problematikker i forhold til den måde, vi har afviklet skriveøvelser på i denne omgang, er, at der ikke har været nok tid til det (Udsagn 7). Vi havde valgt en model, hvor de studerende havde 10-15 minutter til at besvare og diskutere spørgsmålet og skrive det, de var nået frem til, ind i et fælles dokument.

Vi brugte et meget fast format med to gentagelser af 30 min. underviseroplæg og ca. 15 min. skriveøvelser. Derudover blev de studerende også opfordret til at arbejde videre med besvarelserne uden for undervisningstiden og give hinanden skriftlig feedback direkte i dokumentet (hertil mere i afsnit om feedback).

Hvis de studerendes behov for tid og eftertanke ikke tilgodeses i de rette rammer i undervisningen, sættes de studerende i den uheldige situation at skulle producere et ikke tilfredsstillende produkt. En af de lektier, vi tager til os, er at tilbyde de studerende realistiske rammer, inden for hvilke de er i stand til at levere et produkt, som de vil kendes ved. Dette kunne eventuelt løses ved indførsel af nye undervisningsformer som 'flipped classroom', hvor undervisers oplæg foregår på video og indgår i 
forberedelsen hjemmefra. Samtidig kan tiden i lektionerne bruges udelukkende til diskussion og skriveøvelser.

\section{Feedback - peer-to-peer eller underviser-korrektion?}

Udsagn 8:

- " "[...] tjekket for korrekthed - så også det faerdige dokument bliver nyttig for os alle."

Et forslag fra de studerende lød på, at de skrevne produkter skulle tjekkes for korrekthed af underviser (Udsagn 8). Dette forslag tænkes at hænge sammen med, at nogle studerende ikke ønsker feedback fra og diskussion med deres medstuderende, men derimod udelukkende vil interagere med underviser. I skriftligt arbejde af den type, som vi initierede med de studerende, skal begge feedbackmekanismer stilles til rådighed og ikke kun peer-to-peer-dimensionen. Det kan fx opnås ved, at underviseren efter selve skriveøvelsen kommenterer hver gruppes produkt mht. besvarelsens faglige kvalitet. Vi forsøgte så i undervisningen ugen efter den pågældende skriveøvelse at gennemgå besvarelserne på skærmen sammen med klassen, men pga. tidsnød kunne vi ikke systematisk etablere underviserfeedback. Ift. peerto-peer-feedback opfordrede vi specifikt de studerende til at bruge online-feedback i en ugeopgave (uge 38) via Googles kommentarfunktion - men uden for undervisningen. De studerende gav forskellige typer feedback til de 6 opgaver: bekræftende/ros ("Hvor er I gode [...]. Jeg har ikke noget at tilføje", "Godt lavet."), forsigtige opfordringer til afklaringer ("Ikke helt sikker på formulering - hvad vil det sige at foretage søgninger interpersonelt?”, “Vi er ikke sikre på hvad I mener med "lingvistiske aktiviteter"), kontant påpegning af huller i besvarelsen ("Mangler."), eller forespørgsel på definitioner ("Hvad er et verbalt indeks og en "bottom-up" tilgang?"). Kommentarerne er kendetegnet af høflig og afdæmpet sprogbrug ( $f x$ "ikke helt sikker", "ikke sikre"), konstruktivitet og faglig tone. De studerende var sig åbenbart så bevidste om deres medstuderendes forventning, at der er blevet reflekteret over kommentarerne og over, hvordan de kan opfattes i digitale miljøer. Denne egenskab beskrev vi som revisability ovenfor. Vores konklusion ang. feedback på skriftlige tekster er, at åben, systematisk underviserfeedback på holdet er vigtig, men også peer-to-peerfeedback, som i vores eksempler viser en fin bredde af kommentartyper (ros, opfordringer til præciseringer mv.) og vidner om de studerendes beherskelse af de skriftlige genrer i digitale omgivelser.

\section{Konklusion og anbefalinger}

I dette bidrag har vi beskrevet et forsøg på at involvere studerende i forpligtende faglig skrivning og dermed et forsøg på at fremme deres "dybdelæring". De studerende skulle vænne sig til åben faglig dialog, modtage og give konstruktiv feedback og udnytte de læringsperspektiver, der ligger i de nye medier. Omdrejningspunktet 
er "digital skriftlighed", som knytter skriftlighedens dyder (refleksion, dybdelæring, forpligtigelse m.m.) til mulighederne i det digitale, herunder skriftlig online-feedback og muligheden for at udvide læringsoplevelsen til individuel læring, som imødekommer de studerendes forskellige læringsstile og behov for individuel planlægning. De studerende har benyttet sig af disse digitale muligheder, som både vores forsøg med online-feedback og talrige læringsaktiviteter uden for den formelle undervisning vidner om. Vi har gennem vores forsøg fået viden, som vi kan bruge fremover. Det har fx vist sig, at en stor del af de studerendes motivation for at indgå i skriftlige aktiviteter $\mathrm{i}$ undervisningen var instrumentel. Mht. til spørgsmålstyperne har det vist sig, at både åbne, problematiserende og mere snævre, tekstnære spørgsmål har deres berettigelse i det skriftlige arbejde. Førstnævnte egner sig bedst til face-to-face gruppearbejde foran skærmen, men sidstnævnte kan også bearbejdes af den studerende alene og kognitivt. Et andet punkt er, at mange studerende savner mere tid til gruppearbejde. Til sidst efterspurgtes underviserfeedback i stedet for peer-to-peerinput.

Hvilke perspektiver og forbedringsmuligheder kan så udledes af disse erfaringer? Vi har lært, at ifm. almindelig holdundervisning handler disse skriveøvelser om, at de studerende skal bevidstgøres omkring forholdet mellem de læste tekster, fagets pointer og vinkler og til sidst de studerendes output. De studerende føler sig helt klart mere hjemme i den mundtlige diskussion, men ikke så meget i det flow, der er mellem tekst, pointe og output. Derudover kan vi konkludere, at den platform, vi var nået frem til at bruge i dette forløb (Google Docs), fungerede efter formålet. Det var tilstrækkeligt nemt og åbent til, at alle kunne deltage, hvilket gjorde det ideelt til en sådan kollaborativ opgave. Som afslutning har vi følgende anbefalinger $\mathrm{i}$ forhold til afholdelsen af skriveøvelser mhp. at øge de studerendes medansvar og faglige engagement $\mathrm{i}$ og uden for undervisningen:

- Variationen mellem åbne og mere tekstnære spørgsmål har været nyttig i forhold til at motivere de studerendes forberedelse.

- Uddelegering af ansvarsfulde roller til mindst to personer i hver gruppe er med til at sikre øget produktivitet.

- Skriveøvelser i grupper kan give de studerende en følelse af medansvar over for deres medstuderende, som kan motivere forberedelse og faglig deltagelse.

- Der skal være god tid til at diskutere og skrive svar ind i fællesdokumentet.

- Brugen af en digital platform virker mere forpligtende og Google-dokumenter har fungeret rigtig godt til fælles-dokumenter, der kan bruges af flere studerende på samme tid.

- Det lykkedes at forlænge den faglige aktivitet ud over den skemalagte undervisningstid ved brug af den digitale kommentarfunktion. 
Som konklusion kan vi sige, at skriveøvelser på dette fag var med til at øge de studerendes faglige engagement og medansvar på den måde, at de generelt følte et større behov for at forberede sig og deltage i undervisningen, end vi har set på tidligere årgange.

Henriette Roued-Cunliffe er adjunkt ved Det Informationsvidenskabelige Akademi på Københavns Universitet. Hun er DPhil inden for Digital Humanities (University of Oxford) og MSc i Archaeological Computing (University of Southampton). Hun har arbejdet med brugen af digitale platforme inden for humaniora ved Ludwig-Maximilians-Universität München, hvor hun har undervist både studerende og kollegaer i brug af forskellige digitale platforme $i$ forbindelse med forskning $i$ humanistisk og kulturarvsmateriale. Hendes forskningsinteresser ligger inden for data og informationsdeling via digitale platforme, både inden for forskning og i hverdagslivet.

Volkmar Engerer er Dr. Phil. og har loest sprog i Tyskland og arbejdede bl.a. på Institut for Lingvistik, Teknisk Universitet Berlin. I 1997 blev han tysk lektor på Germansk Institut, Aarhus Universitet, hvor han underviste i tysk sprog og grammatik. I 2000 tiltrådte han en stilling som seniorforsker på Statsbiblioteket i Aarhus. Fra ca. 2008 begyndte han at interessere sig for bibliotekets rolle i forhold til loering og publicerede en roekke artikler om tvarfaglighed, informationskompetence, undervisning, e-loering og formidling af eressourcer. I dag er Volkmar Engerer ansat som lektor i informationsvidenskab og kulturformidling på Det Informationsvidenskabelige Akademi, hvor han underviser og forsker inden for loering, kommunikation og i sprog og lingvistiske teoriers rolle i informationsvidenskaben.

\section{Litteratur}

Bødtcher-Hansen, M. (2015). Telefonsamtale, 25.11.2015.

Clark, H. H. \& Brennan, S. E. (1993). Grounding in communication. I R. M. Baecker (red.): Readings in Groupware and Computer-supported Cooperative Work: assisting Human-Human Collaboration. San Mateo,Ca. : Morgan Kaufmann Publishers, 222-223.

Ledelse og kommunikation (2013, February 8). TEACH - Teaching Centre Humanities. Retrieved 25 November 2015, from http://hum.ku.dk/omfakultetet/fakultetsservice/alle/paedagogiskcenter/.

Pachler, N. \& Daly, C. (2011). Key Issues in E-Learning: Research and Practice. London: Continuum International Pub. Group.

Webb, J. \& Powis, C. (2004). Teaching Information Skills: Theory and Practice. London: Facet Publishing. 